\begin{tabular}{|l|l|l|l|l|} 
Share: Social Work Jurnal & VOLUME: 8 & NOMOR: 1 & HALAMAN: $31-38$ & $\begin{array}{l}\text { ISSN:2339 -0042 (p) } \\
\text { ISSN:2528-1577 (e) } \\
\text { Doi: 10.24198/share.v8i1.16111 }\end{array}$ \\
\hline
\end{tabular}

\title{
PENERIMAAN ORANG TUA TERHADAP ANAK DENGAN RETARDASI MENTAL
}

\author{
Meilanny Budiarti S. ${ }^{1}$, Budhi Wibhawa ${ }^{2}$, Ishartono ${ }^{3}$
}
1. Program Studi Kesejahteraan Sosial, Fakultas IImu Sosial Dan IImu Politik, Universitas Padjadjaran meilannybudiarti13@gmail.com

2. Program Studi Kesejahteraan Sosial, Fakultas IImu Sosial Dan IImu Politik, Universitas Padjadjaran budhi.wibhawa@gmail.com

3. Program Studi Kesejahteraan Sosial, Fakultas IImu Sosial Dan IImu Politik, Universitas Padjadjaran kesosish@gmail.com

\begin{abstract}
ABSTRAK
Sebagian orang tua ditakdirkan untuk memiliki anak dengan kondisi yang berbeda dan sering kali dinyatakan sebagai anak yang tidak normal. Dalam kondisi demikian, banyak orang tua yang tidak dapat menerima kenyataan jika anak yang dilahirkannya memiliki kekurangan atau kondisinya tidak sempurna seperti anak-anak lainnya. Hal tersebut pun terjadi pada orang tua yang memiliki anak dengan retardasi mental. Penerimaan orang tua terhadap anak dengan retardasi mental dapat dilihat dari beberapa poin berikut ini, yaitu: gambaran penerimaan orang tua terhadap anak dengan retardasi mental, faktor-faktor penerimaan orang tua, serta proses yang dijalani oleh orang tua hingga penerimaan terhadap anak dengan retardasi mental dapat terwujud. Hal ini dikarenakan bagi anak dengan retardasi mental, orang tua merupakan orang yang terpenting serta guru pertama baginya dan sebagai sosok untuk memberikan dorongan, pujian maupun umpan balik. Penerimaan orang tua terhadap anak dengan retardasi mental sangat dipengaruhi oleh tingkat kestabilan dan kematangan emosi dari orang tua, tingkat pendidikan, status sosial ekonomi, dukungan anggota keluarga, struktur dalam keluarga, dan kultur yang melatarbelakangi keluarga.
\end{abstract}

Kata kunci: penerimaan orang tua, anak, retradasi mental

\begin{abstract}
Some parents are destined to have children with different conditions and are often expressed as abnormal children. Under these circumstances, many parents can not accept the reality if the child has a deficiency or the condition is not perfect like the other children. It also happens to parents who have children with mental retardation. Parental acceptance of children with mental retardation can be seen from the following points, namely: the description of parents' acceptance of the child with mental retardation, the factors of parent acceptance, and the process undertaken by parents to acceptance of children with mental retardation can materialized. This is because for a child with mental retardation, the parent is the most important person and the first teacher for him and as a figure to give encouragement, praise and feedback. Parental acceptance of children with mental retardation is strongly influenced by the degree of stability and emotional maturity of parents, education level, socioeconomic status, family support, family structure, and family background culture.
\end{abstract}

Keywords: acceptance of parents, children, mental retardation 


\section{PENDAHULUAN}

Ketika sepasang suami istri menunggu kelahiran buah hatinya, maka harapannya adalah akan dikaruniai anak yang terlahir dengan kondisi sehat dan sempurna. Namun, fakta menyatakan bahwa tidak semua pasangan suami istri dianugerahi anak dengan kondisi yang sehat dan sempurna. Sebagian orang tua ditakdirkan untuk memiliki anak dengan kondisi yang berbeda dan sering kali dinyatakan sebagai anak yang tidak normal.

Situasi tersebut sejalan dengan ungkapan ahli kesehatan mental, Payne dan Patton (1981) yang menyatakan bahwa umumnya orang melihat seorang individu itu normal atau tidak, adalah dari perilakunya. Sehingga masih banyak orang tua yang belum dapat menerima jika anak yang dilahirkannya memiliki kekurangan atau kondisinya tidak sempurna seperti anak-anak lainnya. Hal tersebut pun terjadi pada orang tua yang memiliki anak dengan berketerbelakangan (retardasi) mental / mental retardation (MR).

Menurut Ducan \& Moses (dalam Garguilo, 1985), orang tua yang memiliki anak dengan retardasi mental pada awalnya akan mengalami shock saat mengetahui kondisi anaknya tersebut. Namun, pada akhirnya orang tua akan dapat menerima anak mereka apa adanya, walaupun pada sebagian orang tua memerlukan waktu yang tidak sebentar (lama) untuk memiliki kesiapan dalam menerima kondisi anaknya yang terkena retardasi mental.

Untuk dapat menerima kondisi anaknya, orang tua biasanya harus melalui proses panjang, terutama bagi seorang ibu yang lebih banyak menggunakan perasaan dan dalam situasi seperti ini akan menekan perasaan ibu tersebut. Umumnya dalam kondisi seperti ini, pada diri orang tua khususnya pada diri ibu akan terbentuk pandangan menyalahkan diri sendiri, memandang dirinya sebagai orang tua yang gagal, tidak berharga dan orang tua yang tidak sempurna. Bila kita coba untuk berempati pada orang tua dengan anak retardasi mental, maka wajar kiranya jika orang tua merasa sedih, kecewa dan bingung atas kondisi yang harus mereka hadapi, terlebih telah menimpa buah hati mereka yang sudah didambakan kelahirannya.

Dalam proses penerimaan orang tua terhadap anak dengan retardasi mental, selain tekanan berbagai perasaan yang sangat mengganggu secara emosional tersebut, orang tua pun sering kali mengalami stres dalam menjaga dan merawat anak dengan retardasi mental dalam kehidupan sehari-hari, karena anak dengan retardasi mental tentunya membutuhkan perhatian yang lebih banyak bila dibandingkan dengan merawat dan mengasuh anak normal pada usianya.

Dalam kondisi demikian, orang tua dengan anak retardasi mental membutuhkan dukungan dari keluarga (keluarga besar) untuk dapat menguatkan perasaan mereka, hingga kemudian orang tua pun dapat menerima keberadaan anaknya. Dukungan keluarga merupakan hal terpenting dalam proses penyesuaian diri individu. Hal ini dikarenakan keluarga memberikan sebuah ekspresi kehangatan, empati dan penerimaan yang ditunjukkan keluarga (Santrock, 2002). Lebih lanjut Rodin \& Salovely dalam Smet (1994) menyatakan bahwa keluarga merupakan sumber dukungan yang paling penting. Pasangan atau keluarga merupakan sumber utama dukungan yang paling berpengaruh bagi individu (ibu khususnya). Di sisi lain, anak dengan retardasi mental pun membutuhkan penerimaan, pengertian, perhatian, cinta dan kasih sayang dari seluruh anggota keluarga, teman-teman bermain serta lingkungan sekitarnya.

Sebagai sebuah setting dalam bidang keilmuan pekerjaan sosial, bekerja bersama keluarga adalah salah satu strategi yang dapat dilakukan oleh seorang pekerja sosial. Dengan demikian, kajian mengenai penerimaan orang tua terhadap anak dengan retardasi mental menjadi menarik untuk dilakukan, terutama untuk memperkaya strategi dan menguatkan metode penanganan orang dengan retardasi mental melalui penguatan keluarga yang 
dimulai dari sikap penerimaan orang tua sebagai kunci keberhasilan dalam menanganai anak dengan retardasi mental.

\section{TINJAUAN PUSTAKA}

Retardasi mental (mental retardation) adalah individu yang memiliki fungsi intelektual keseluruhan yang secara makna berada di bawah rata-rata yang menyebabkan atau berhubungan dengan gangguan pada perilaku adaptif dan bermanifestasi selama periode perkembangan yaitu sebelum usia 18 tahun (dalam DSM-IV / Diagnostik and Statistical Manual of Mental Disorder edisi keempat, 1994).

Oleh beberapa ahli karakterisrik dan klasifikasi anak dengan retardasi mental dibagi menjadi dua, yaitu anak sebelum 18 tahun dan penderita retardasi mental yang berusia sesudah 18 tahun. Payne \& Patton, (1981) mengatakan bahwa anak dengan retardasi mental yang berusia sebelum atau di bawah 18 tahun dapat dibagi menjadi empat klasifikasi, yaitu; (1). Mild yaitu kesulitan dalam hal akademik dan berperilaku, (2). Moderate di mana anak bisa mengurus dirinya sendiri, namun dalam beberapa hal perlu bantuan dari orang lain, (3). Severe di mana anak mengalami kesulitan dalam menjaga diri, kurangnya koordinasi motorik, gangguan dalam kemampuan berbicara dan gangguan dalam kemampuan berinteraksi, (4). Profound di mana anak mengalami retardasi mental dalam setiap perkembangannya dan harus memperoleh perawatan total.

Seperti halnya kondisi anak dengan retardasi mental yang dibedakan berdasarkan masing-masing klasifikasinya, kesiapan orang tua untuk menerima keberadaan anak dengan retardasi mental pun ada tahapannya. Seperti yang diungkapkan oleh Kiibler-Ross (dalam Garguilo, 1985) bahwa tahapan penerimaan orang tua terhadap anak dengan retardasi mental dibagi menjadi tiga tahapan besar, yaitu:

\section{Primary Phase}

$$
\text { a. Shock }
$$

Orang tua merasa terguncang, tidak mencapai apa yang telah terjadi. Timbul tingkah laku yang tidak rasional di tandai dengan menangis secara terus-menerus dan perasaan tidak berdaya.

b. Denial.

Orang tua menolak keadaan keluarganya dengan cara merasionalisasi kekurangan yang ada atau mencari penegasan dari para ahli bahwa tidak ada kekurangan.

c. Grief and Deppresion

Merupakan reaksi yang wajar dan tidak perlu dihindari. Dengan adanya perasaan ini orang tua mengalami masa transisi, di mana harapan masa lalu mengenai 'anak yang sempurna' tidak sesuai dengan kenyataan yang ada saat ini.

2. Secondary Phase

a. Ambivalence

'Kecacatan' yang dialami oleh salah satu anggota keluarga dapat meningkatkan intensitas kasih sayang sekaligus perasaan benci. Dalam hal ini seseorang dapat mendedikasikan sebagian besar waktunya untuk anak atau justru menolak memberikan kasih sayang kepada anak dan menganggap anaknya tidak berguna.

b. Guilty Feeling

Perasaan bersalah karena menganggap dirinyalah yang menyebabkan anaknya mengalami cacat, dan dirinya akan dihukum karena dosanya di masa lalu.

c. Anger.

Perasaan ini dapat ditunjukkan dengan dua cara. Pertama, timbulnya pertanyaan: mengapa saya? Kedua, displacement di mana rasa marah ditunjukkan kepada orang lain, seperti dokter, terapis atau anggota keluarga yang lain.

d. Shame and embarrament.

Perasaan ini timbul saat menghadapi lingkungan sosial yang menolak, mengasihani atau mengejek 'kecacatan' anak. 
3. Tertiary Phase

\section{a. Bergaining}

Suatu strategi di mana orang tua membuat perjanjian dengan Tuhan, ilmu pengetahuan atau pihak manapun yang mampu membuat anaknya menjadi kembali normal.

b. Adaptation dan reorganization.

Adaptation merupakan proses bertahap yang membutuhkan waktu dan berkurangnya rasa cemas dan reaksi emosional lainnya, sedangkan reorganization adalah kondisi di mana orang tua merasa nyaman dengan situasi yang ada dan terdapat rasa percaya diri akan kemampuan mereka untuk merawat dan mengasuh.

c. Acceptance dan Adjustment.

Pada phase ini seseorang tidak hanya menerima kondisi penderita tetapi juga menerima kekuatan dan kelemahan dirinya sendiri. Adjustment atau penyesuaian diri adalah tambahan untuk menjelaskan konsep acceptance, di mana terdapat suatu tindakan positif yang bergerak maju.

Penerimaan orang tua merupakan suatu efek psikologis dan perilaku dari orang tua pada anaknya seperti rasa sayang, kelekatan, kepedulian, dukungan dan pengasuhan di mana orang tua tersebut bisa merasakan dan mengekspresikan rasa sayang kepada anaknya (Hurlock, 1997). Pengertian penerimaan orang tua yang dipaparkan oleh Hurlock (1997) tersebut terdapat beberapa aspek yang bisa dijadikan tolak ukur penerimaan orang tua diantaranya adalah aspek rasa sayang, kelekatan, kepedulian, dukungan, dan pengasuhan. Hal ini senada dengan yang diungkapkan oleh Rohner et al (2007) bahwa aspek penerimaan orang tua terdiri dari kehangatan kasih sayang, perawatan, kenyamanan, perhatian, pemeliharaan, serta dukungan dari orang tua untuk anaknya.

Penerimaan orang tua terhadap anak dengan retardasi mental dapat dilihat dari beberapa poin berikut ini, yaitu: gambaran penerimaan orang tua terhadap anak dengan retardasi mental, faktor-faktor penerimaan orang tua, serta proses yang dijalani oleh orang tua hingga penerimaan terhadap anak dengan retardasi mental dapat terwujud. Hal ini dikarenakan bagi anak dengan retardasi mental, orang tua merupakan orang yang terpenting serta guru pertama baginya dan sebagai sosok untuk memberikan dorongan, pujian maupun umpan balik (Heward, 1996).

Porter (dalam Byrd, 1985), mengungkapkan beberapa ciri seseorang telah menerima (accept) terhadap keadaan orang lain, yaitu:

1. Menunjukkan sikap menerima dan memberikan perasaan positif.

2. Komunikasi tetap terjaga.

3. Mendengarkan dengan pikiran yang terbuka terhadap suatu permasalahan.

4. Tidak memaksa untuk mengubah apa yang telah menjadi dasar (potensi) dari bawaan seseorang.

5. Menerima segala keterbatasan yang ada.

6. Memberikan dukungan dan cinta setiap waktu, berbagi dalam suka dan duka, tetap mendukung meskipun gagal.

7. Mencintai tanpa syarat, tidak meminta cinta yang sama seperti yang telah ia berikan.

8. Membuat orang lain mengetahui bahwa dirinya mencintai dan memberikan kasih sayang kepada orang tersebut.

9. Senang bersama orang tersebut dan menikmati apa yang mereka lakukan bersama.

Porter (dalam Byrd, 1985), menyebutkan beberapa ciri-ciri seseorang telah menerima (accept) keadaan orang lain, yaitu:

1. Menunjukkan sikap menerima dan memberikan perasaan positif.

2. Komunikasi tetap terjaga.

3. Mendengarkan dengan pikiran yang terbuka terhadap suatu permasalahan.

4. Tidak memaksa untuk mengubah apa yang telah menjadi dasar (potensi) dari bawaan seseorang.

5. Menerima segala keterbatasan yang ada. 
6. Memberikan dukungan dan cinta setiap waktu, berbagi dalam suka dan duka, tetap mendukung meskipun gagal.

7. Mencintai tanpa syarat, tidak meminta cinta yang sama seperti yang telah ia berikan.

8. Membuat orang lain mengetahui bahwa dirinya mencintai dan memberikan kasih sayang kepada orang tersebut.

9. Senang bersama orang tersebut dan menikmati apa yang mereka lakukan bersama.

\section{METODE}

Metode yang digunakan adalah studi literature, yakni dengan melakukan mengumpulkan dan pengkajian data baik dari buku, jurnal, maupun website (internet) yang berkaitan dengan topik yang diteliti, yakni penerimaan keluarga terhadap anak dengan retardasi mental. Penggunaan metode studi literature dalam kajian ini dimaksudkan untuk memperoleh gambaran yang luas berdasarkan kajian konseptual maupun hasil penelitian sebelumnya dari berbagai sumber referensi terkait isu penerimaan orang tua terhadap anak dengan retardasi mental. Dengan demikian, diharapkan dapat menambah khasanah keilmuan dalam bidang praktik pekerjaan sosial dengan keluarga.

\section{HASIL DAN PEMBAHASAN}

Penerimaan orang tua terhadap anak dengan retardasi mental tidak mudah untuk dapat muncul seketika pada saat orang tua mengetahui hasil diagnosa dokter yang menyatakan retardasi mental terhadap anak mereka. Orang tua yang mendapat "vonis" bahwa buah hati mereka termasuk pada anak berkebutuhan khusus biasanya belum bisa langsung menunjukkan suatu penerimaan terhadap sang anak. Sarasvati (2004) mengungkapkan bahwa untuk mencapai suatu tahap di mana orang tua benar-benar telah menerima kondisi anak, maka orang tua biasanya akan melalui beberapa tahapan.

Sarasvati (2004) membagi tahap-tahap penerimaan orang tua menjadi beberapa tahapan sebagai berikut:

1. Tahap denial (penolakan)

Dimulai dari rasa tidak percaya saat menerima diagnosa dari seorang ahli. Perasaan orang tua selanjutnya akan diliputi kebingungan. Bingung atas arti dan makna dari hasil diagnosa, bingung akan apa yang harus dilakukan, sekaligus bingung mengapa hal ini dapat terjadi pada anak mereka. Kebingungan ini sangat manusiawi, karena umumnya, orang tua mengharapkan yang terbaik untuk keturunan mereka. Terkadang, orang tua memiliki perasaan yang kuat untuk menolak keadaan bahwa anaknya merupakan anak dengan retardasi mental. Tindakan penolakan ini bukan untuk meredakan kesedihan orang tua, melainkan justru akan semakin menyiksa perasaan orang tua. Tidak mudah bagi orang tua manapun untuk dapat menerima apa yang sebenarnya terjadi terhadap anak mereka. Terkadang, dalam perasaan orang tua terselip rasa malu untuk mengakui bahwa hal tersebut terjadi pada keluarganya. Keadaan ini bisa menjadi bertambah buruk, jika keluarga tersebut mengalami tekanan sosial dari lingkungan masyarakatnya bahwa mereka tidak dapat memberikan keturunan yang "sempurna". Terkadang, dalam hati orang tua muncul pernyataan”tidak mungkin hal ini terjadi pada anak saya” atau "tidak pernah terjadi keadaan seperti ini di dalam keluarga kami” (Smith, 2003)

2. Tahap anger (marah)

Tahapan yang ditandai dengan adanya reaksi emosi/marah pada orangtua yang memiliki anak dengan retardasi mental dan orang tua menjadi peka dan sensitif terhadap masalah-masalah kecil yang pada akhirnya menimbulkan kemarahan. Kemarahan tersebut biasanya ditujukan pada dokter, saudara, keluarga, atau teman-teman. Pernyataan yang sering 
muncul dalam hati orang tua (sebagai reaksi atas rasa marah) adalah muncul dalam bentuk "Tidak adil rasanya...", "Mengapa kami yang mengalami hal ini?" atau ”Apa salah kami?” (Smith, 2003)

3. Tahap bargainning (tawar - menawar) Pada tahapan ini, orang tua mulai berusaha untuk menghibur diri dengan pernyataan seperti "Mungkin kalau kami menunggu lebih lama lagi, keadaan akan membaik dengan sendirinya” dan berpikir tentang upaya apa yang akan dilakukan untuk membantu proses penyembuhan anak. (Safaria, 2005)

4. Tahap Depression (depresi)

Tahapan yang muncul dalam bentuk putus asa dan kehilangan harapan. Kadang-kadang depresi dapat juga menimbulkan rasa bersalah, terutama pada diri ibu, yang khawatir apakah keadaan anak mereka saat ini sebagai akibat dari kelalaian pada diri ibu selama hamil, atau akibat dosa di masa lalu. Ayah pun sering dihinggapi rasa bersalah, karena merasa tidak dapat memberikan keturunan yang sempurna (Safaria, 2005). Putus asa, sebagai bagian dari depresi, akan muncul saat orang tua mulai membayangkan masa depan yang akan dihadapi oleh anak mereka. Terutama jika mereka memikirkan siapa yang dapat mengasuh anak mereka, pada saat mereka sebagai orang tuanya meninggal. Harapan atas masa depan anak menjadi keruh, dan muncul dalam bentuk pertanyaan "Akankah anak kami mampu untuk hidup mandiri dan berguna bagi orang lain?”. Pada tahap depresi, orang tua cenderung murung, menghindar dari lingkungan sosial terdekat, lelah sepanjang waktu dan kehilangan gairah hidup.

5. Tahap Acceptance (penerimaan)

Tahapan di mana orang tua telah mencapai pada titik pasrah dan mencoba untuk menerima keadaan anaknya dengan tenang. Orang tua pada tahap ini cenderung mengharapkan yang terbaik sesuai dengan kapasitas dan kemampuan anak mereka (Safaria, 2005). Kemampuan penyesuaian diri dari seorang ibu akan mempengaruhi kondisi psikologis diri ibu sendiri dan juga akan mempengaruhi perkembangan anak dengan retardasi mental. Ibu yang mampu menyesuaikan diri dengan baik akan memiliki kondisi psikologis yang sehat dan hal ini akan berdampak positif bagi perkembangan anaknya. Sebaliknya, ibu yang tidak mampu menyesuaikan diri dengan baik akan memiliki kondisi psikologis yang tidak sehat dan akan berdampak negatif bagi perkembangan anaknya. (Gunarsa, 2003).

Sejalan dengan tahapan penerimaan orang tua terhadap anak dengan retardasi mental tersebut di atas, Surasvati (2004) pun mengungkapkan bahwa banyak hal yang mempengaruhi kesiapan orang tua dalam mengahadapi kondisi anak mereka yang didiagnosa menderita retardasi mental, yaitu sebagai berikut:

1. Dukungan dari keluarga besar.

Dengan semakin kuatnya dukungan keluarga besar, maka orang tua akan terhindar dari merasa sendirian, sehingga menjadi orang tua akan lebih kuat dalam menghadapi keadaan karena mereka mendapatkan dukungan dari keluarga.

2. Kemampuan keuangan keluarga.

Keuangan keluarga yang memadai, memberikan kesempatan yang lebih baik bagi orang tua untuk memberikan pengobatan bagi anak mereka.

3. Latar belakang agama yang kuat, relatif membuat orang tua lebih mampu untuk dapat menerima kondisi anak yang menderita retardasi mental, karena orang tua memiliki kepercayaan bahwa cobaan itu datang untuk kebaikan perkembangan spiritualnya.

4. Sikap para ahli yang mendiagnosa anak. Dokter ahli yang simpatik membuat orang tua merasa dimengerti dan dihargai.

5. Tingkat pendidikan, semakin tinggi tingkat pendidikan orang tua, maka relatif makin cepat untuk dapat menerima 
kenyataan dan segera mencari upaya penyembuhan.

6. Status perkawinan yang harmonis memudahkan suami istri untuk bekerja saling bahu membahu dalam menghadapi cobaan hidup yang dialami.

7. Sikap masyarakat umum.

Yang paling sulit diubah adalah sikap masyarakat umum. Makin rendah pengetahuan masyarakat terkait kondisi retardasi mental pada anak, maka akan semakin sulit bagi masyarakat untuk dapat menerima kondisi anak dengan retardasi mental.

8. Usia yang matang dan dewasa pada pasangan suami istri, memperbesar kemungkinan orang tua untuk menerima diagnosa dengan relatif lebih tenang.

9. Saranan penunjang seperti pusat-pusat terapi, sekolah khusus, dokter ahli, dan pusat konseling keluarga, merupakan sarana penunjang yang sangat dibutuhkan oleh orang tua dalam mengasuh anakanak dengan retardasi mental.

Tingkat penerimaan orang tua dalam menerima anak dengan retardasi mental sangat dipengaruhi oleh tingkat kestabilan dan kematangan emosi dari orang tua, tingkat pendidikan, status sosial ekonomi, dukungan anggota keluarga, struktur dalam keluarga, dan kultur yang melatarbelakangi keluarga. Ketika orang tua menunjukkan sikap kerjasama, kehangatan, saling menghormati, komunikasi yang seimbang, dan penyesuaian terhadap kebutuhan masing-masing, maka hal tersebut akan membantu anak dengan retardasi mental dalam membentuk sikap yang positif. Sebaliknya, bila orang tua menunjukkan koordinasi yang buruk, sikap meremehkan yang dilakukan secara aktif oleh orang tua terhadap anak, kurangnya kerjasama dan kehangatan terhadap anak, dan pemutusan hubungan oleh salah satu orang tua terhadap anak merupakan kondisi yang membuat anak menghadapi risiko terjadinya gangguan perkembangan. (Santrock, 2007).

\section{SIMPULAN}

Berbagai upaya yang dilakukan oleh orang tua untuk dapat menerima keadaan anak dengan retardasi mental tidak selalu berakhir dengan adanya sikap penerimaan yang muncul dalam diri orang tua, karena ada kalanya dalam beberapa kasus, orang tua tetap tidak mampu untuk dapat menerima kondisi anak mereka sepenuhnya dan hal inilah yang pada akhirnya memunculkan perilaku penolakan terhadap anak mereka. Namun, jika orang tua telah benar-benar menyadari dan memahami kondisi anaknya dan menerima apapun yang terjadi pada anaknya tersebut, maka akan muncul sikap-sikap penerimaan terhadap kekurangan serta keterbatasan yang ada pada anak mereka. Tentunya hal ini sangat dipengaruhi oleh tingkat kestabilan dan kematangan emosi dari orang tua, tingkat pendidikan, status sosial ekonomi, dukungan anggota keluarga, struktur dalam keluarga, dan kultur yang melatarbelakangi keluarga.

\section{DAFTAR PUSTAKA}

APA. (1994). Diagnostik and Statistical Manual of Mental Disorder. $4^{\text {th }}$ ed. Washington: American Psychiatric Association

Byrd, O.E. (1956). Family life source book. California: Stadford University.

Garguilo, R.M. (1985). Working with parents of exeptional children: A Guide for Profesionals. Boston: Houghton Mifflin Company.

Gunarsa, Singgih D. (2003). Psikologi Perkembangan. Jakarta: BPK Gunung Mulia.

Heward, William L. (1996). Exeptional children: An Introduction to Special Education. $5^{\text {th }}$ ed. New Jersey: Prentice-Hall, Inc.

Hurlock, E.B. (1997). Psikologi Perkembangan Suatu Pendekatan Sepanjang Rentang Kehidupan. Jakarta: Penerbit Erlangga. 


\begin{tabular}{|c|c|c|c|c|}
\hline Share: Social Work Jurnal & VOLUME: 8 & NOMOR: 1 & HALAMAN: $31-38$ & $\begin{array}{l}\text { ISSN:2339 -0042 (p) } \\
\text { ISSN:2528-1577 (e) } \\
\text { Doi: 10.24198/share.v8i1.16111 }\end{array}$ \\
\hline
\end{tabular}

Payne, J., \& Patton, J.R. (1981). Mental Retardation, Ohio: Bell \& Howel.

Rohner, Ronal. P. et al (2007, May). Parental Acceptance-Rejection Theory, Methods, Evidence, and Implications. Diakses pada tanggal16 Maret 2012 dari

http://www.cspar.uconn.edu/Introducti on_to_Parental_Acceptance.pdf

Safaria. (2005). Interpersonal Intelligence: MetodePengembanganKecerdasan Interpersonal Anak. Yogyakarta: Amara Books.

Santrock. (2002). Life Spam Development. Jakarta: Erlangga. Hlm.41

Santrock, John W. (2007). Perkembangan Anak. Jilid 1 Edisi kesebelas. Jakarta: PT. Erlangga.

Sarasvati. (2004). Meniti pelangi: Perjalanan seorang ibu yang tak kenal menyerah dalam membimbing putranya keluar dari belenggu ADHD dan autisme. Jakarta: PT Elex Media Komputindo.

Smet. (1994). Psikologi Kesehatan. Jakarta: Grasindo. Hlm. 133

Smith, Patricia McGill. (2003). You Are Not Alone. News Digest 20 (3rd Edition). NICHCY: $\quad 1.800 .695 .0285, \quad 2-6$. Diakses pada tanggal 16 Maret 2012 dari http://nichcy.org/wpcontent/uploads/docs/nd20.pdf 